University of Nebraska - Lincoln

DigitalCommons@University of Nebraska - Lincoln

Nebraska Beef Cattle Reports

Animal Science Department

2017

\title{
Effect of Harvest Method on Digestibility of Corn Residue
}

\author{
Tasha M. King \\ University of Nebraska - Lincoln \\ Melissa L. Jolly-Breithaupt \\ University of Nebraska-Lincoln, melissa_jolly_brethaupt@unl.edu \\ Jana L. Gramkow Gramkow \\ University of Nebraska-Lincoln, jharding3@unl.edu \\ Terry J. Klopfenstein \\ University of Nebraska - Lincoln, tklopfenstein1@unl.edu \\ Jim C. MacDonald \\ University of Nebraska-Lincoln, jmacdonald2@unl.edu
}

Follow this and additional works at: https://digitalcommons.unl.edu/animalscinbcr

Part of the Large or Food Animal and Equine Medicine Commons, Meat Science Commons, and the Veterinary Preventive Medicine, Epidemiology, and Public Health Commons

King, Tasha M.; Jolly-Breithaupt, Melissa L.; Gramkow, Jana L. Gramkow; Klopfenstein, Terry J.; and MacDonald, Jim C., "Effect of Harvest Method on Digestibility of Corn Residue" (2017). Nebraska Beef Cattle Reports. 933.

https://digitalcommons.unl.edu/animalscinbcr/933

This Article is brought to you for free and open access by the Animal Science Department at DigitalCommons@University of Nebraska - Lincoln. It has been accepted for inclusion in Nebraska Beef Cattle Reports by an authorized administrator of DigitalCommons@University of Nebraska - Lincoln. 


\section{Effect of Harvest Method on Digestibility of Corn Residue}

\author{
Tasha M. King \\ Melissa L. Jolly-Breithaupt \\ Jana L. Gramkow \\ Terry J. Klopfenstein \\ Jim C. MacDonald
}

\section{Summary with Implications}

Corn residues can be an economical forage source for producers and advanced harvest methods have increased the quality of baled residue. A digestion study was conducted to evaluate the effects of harvest method of corn residues (low-stem, highstem, and conventional) on digestibility in lambs. Samples from total fecal collection were dried 1 of 3 ways to determine effects on digestibility estimates. Corn residue containing low-stem had greatest overall digestibility with high-stem residue being intermediate and conventional harvesting having the lowest digestibility. Drying method had no effect on digestibility estimates.

\section{Introduction}

Advancements in harvest technologies have improved the feeding quality of baled corn residue. The New Holland Cornrower corn head allows producers to adjust the proportion of stem being cut and baled. Changing the bale composition by increasing the ratio of husk and leaf to stem allows for improved digestibility, due to the greater digestibility of husk (2016 Nebraska Beef Cattle Report, pp. 76-78). Previous experiments (2016 Nebraska Beef Cattle Report, pp. 81-83) have reported when the proportion of stem in the baled residue is reduced, in vitro OM digestibility (IVOMD) improves. Additionally, improved ADG was observed with low-stem residue $(1.71 \mathrm{lb})$, compared with conventionally baled corn residue $(1.39 \mathrm{lb})$.

In vitro procedures are variable, an issue often corrected by using known standards

(C) The Board Regents of the University of Nebraska. All rights reserved. from in vivo trials. Developing standards for residues is important to allow for proper adjustments to in vitro digestibility estimates. Various methods are used to dry samples during in vivo trials which may affect the digestibility estimates. The objectives of this study were to 1 ) determine the effect of harvest method (low-stem, highstem, and conventional) on digestibility and quality of corn residues and 2) determine the effect of drying method for feces on digestibility estimates.

\section{Procedure}

An 85-d digestion study was conducted utilizing 9 crossbred wethers (initial $\mathrm{BW}=93.4 \mathrm{lb}, \pm 16.3 \mathrm{lb}$ ) divided into 3 blocks based on initial BW. Wethers were assigned randomly to 1 of 3 treatments. The treatments consisted of 3 residue-based diets containing corn residue harvested with 1 of 3 methods (low-stem, high-stem, and conventional). All diets contained $70 \%$ residue, $27 \%$ Sweet Bran ${ }^{\oplus}$, and 3\% brome grass hay (DM basis, Table 1). Corn residues and brome grass hay were ground using a 1-in screen. Low-stem and highstem corn residues were obtained using a New Holland Cornrower Corn Head (Straeter Innovation, Inc.). The Cornrower corn head was described in the 2015 Nebraska Beef Cattle Report (pp. 62-63) and harvested 2 rows of stem for the low-stem corn residue bales and all 8 rows of stem for the high-stem corn residue. Conventional harvest method was also used on the same field to obtain conventionally harvested corn residue bales (raked and baled). The digestion study consisted of 4 periods in which the experimental treatments were applied. Sweet $\mathrm{Bran}^{\circledast}$ and brome grass hay were fed at a 9:1 ratio in a fifth period for determination of residue digestibility by difference. This allowed for calculation of total fecal output from the Sweet Bran ${ }^{\circledR}$ and brome grass that contributed to fecal output of the other 4 periods. Digestibility of the residue diets were correct by subtracting the contribution of Sweet Bran ${ }^{\circ}$ and brome grass hay in feces.

The periods were $17 \mathrm{~d}$ in length allowing for $10 \mathrm{~d}$ of adaptation and $7 \mathrm{~d}$ for total fecal collection. Wethers were placed in metabolism crates with fecal bags on the evening of $d 10$. Feed was offered twice daily at 0800 and $1600 \mathrm{hrs}$ with $50 \%$ of daily $\mathrm{DM}$ fed at each feeding. Feed refusals were collected each morning at 0800 and fed back to wethers with adjusted 0800 feeding to prevent sorting of least digestible plant parts. Samples of individual feedstuffs were taken on d 10 and d 14 and dried to correct for DM of each period. At the end of each period, feces were composited and mixed. Subsamples were taken and dried utilizing

Table 1. Diet composition (\% DM)

\begin{tabular}{lcccc}
\hline & Low-stem & High-stem & Conventional & SBB $^{1}$ \\
\hline Low-stem corn residue & 64.18 & & & \\
High-stem corn residue & & 64.18 & & \\
Conventional corn residue & & & 64.18 & \\
Sweet Bran & & 29.76 & 29.76 & 86.24 \\
Brome grass hay & 29.76 & 3.31 & 3.31 & 9.59 \\
Limestone & 3.31 & 0.75 & 0.75 & 2.17 \\
Supplement & 0.75 & 2.00 & 2.00 & 2.00 \\
\hline
\end{tabular}

${ }^{1} \mathrm{SBB}$ represents a 9:1 ratio diet of Sweet Bran ${ }^{\circ}$ to brome grass hay. 
Table 2. Effect of drying method on digestibility estimates.

\begin{tabular}{cccccc}
\hline & $60^{\circ} \mathrm{C}$ & $100^{\circ} \mathrm{C}$ & Freeze Dry & SEM & $P$-value \\
\hline OMD, \% & 52.0 & 52.8 & 52.7 & 0.69 & 0.63 \\
NDFD, $\%$ & 52.8 & 52.4 & 51.8 & 0.73 & 0.62 \\
\hline
\end{tabular}

Table 3. Effect of harvest method of corn residue on intake and total tract digestibility.

\begin{tabular}{|c|c|c|c|c|c|}
\hline & Low-stem & High-stem & Conventional & SEM & $P$-value \\
\hline \multicolumn{6}{|l|}{$\mathrm{DM}$} \\
\hline Intake, \%BW/d & 1.36 & 1.43 & 1.49 & 0.11 & 0.45 \\
\hline digestibility, \% & $51.74^{\mathrm{a}}$ & $47.22^{\mathrm{ab}}$ & $46.05^{\mathrm{b}}$ & 1.85 & 0.05 \\
\hline \multicolumn{6}{|l|}{$\mathrm{OM}$} \\
\hline Intake, \%BW/d & 1.31 & 1.32 & 1.40 & 0.10 & 0.60 \\
\hline digestibility, \% & $55.56^{\mathrm{a}}$ & $51.05^{\mathrm{b}}$ & $51.41^{\mathrm{b}}$ & 1.72 & 0.06 \\
\hline \multicolumn{6}{|l|}{$\mathrm{NDF}$} \\
\hline Intake, $\% \mathrm{BW} / \mathrm{d}$ & 1.13 & 1.12 & 1.10 & 0.08 & 0.94 \\
\hline digestibility, \% & $58.53^{\mathrm{a}}$ & $52.37^{\mathrm{b}}$ & $44.46^{\mathrm{c}}$ & 1.85 & $<0.01$ \\
\hline
\end{tabular}

a,b,c Means with differing superscripts differ $(P<0.05)$

1 of 3 techniques: 1$) 60^{\circ} \mathrm{C}$ forced air oven for $72 \mathrm{~h}$; 2) $100^{\circ} \mathrm{C}$ forced air oven for 72 $\mathrm{h}$; or 3 ) freeze drying. Dried samples were composited and ground through a 1-mm screen of a Wiley mill. Feedstuff samples were ground first through a 2 -mm screen of a Wiley mill and additionally through a 1-mm screen. Samples were then analyzed for DM, OM, and NDF.

Data were analyzed using the MIXED procedure of SAS (SAS Institute, Inc., Cary, NC). Lamb served as the experimental unit with period included in the model as a fixed effect. The effect of drying method, harvest method, and lamb were examined.

\section{Results}

Drying method did not affect digestibility determination for either OM digestibility (OMD) or NDF digestibility (NDFD; $P=$ 0.63 and 0.62 ; respectively; Table 2 ). Intakes and digestibility estimates are reported for residue with Sweet $\mathrm{Bran}^{\circledR}$ and brome grass hay component removed (Table 3 ). Intakes were calculated from feed samples dried with the $60^{\circ} \mathrm{C}$ forced air oven. The Sweet Bran $^{\star}$ and brome grass hay component had

\section{Conclusions}

Harvest methods available allow the proportion of stem to be adjusted in the bale. The lack of difference in overall digestibility between high-stem and conventional would suggest similar proportion of plant components were harvested. Decreasing the number of stems cut to produce a low-stem bale, led to an increased overall digestibility which is likely due to the increased proportion of husk, leaf, and cob compared to the proportion of stem. Increasing the proportion of highly digestible components of corn residue in a bale can lead to increased quality.

Tasha M. King, graduate student

Melissa L. Jolly-Breithaupt, research technician

Jana L. Gramkow, research technician

Terry J. Klopfenstein, professor emeritus, Animal Science

Jim C. MacDonald, associate professor, Animal Science digestibility estimates of 76.0, 79.1, and 75.5\% for DM, OM, and NDF; respectively. No differences in DM intake, OM intake or NDF intake were observed among residue types $(P>0.45)$. Low-stem had greater DM digestibility (DMD) than conventional $(P=$ $0.02)$ and had a tendency to be greater than high-stem $(P=0.06)$. There were no differences in $\mathrm{DMD}(P=0.63)$ or $\mathrm{OMD}(P=$ 0.86 ) between high-stem and conventional residue. High-stem and conventional both contained all 8 rows of stem, supporting the findings that DMD and OMD were similar allowing an average estimate (47 and 51\%, respectively), to be used for the high-stem and conventional residues. High-stem had a NDFD greater than conventional $(P<$ 0.01 ). This observation may suggest the conventional harvest method lost husk and resulted in a larger proportion of stem being gathered into the bale during raking. Low-stem had the greatest OMD and NDFD $(P<0.05)$ compared with high-stem and conventional which supports previous findings that by decreasing the proportion of stem in the bale, the quality of the corn residue increases. 